\title{
O futuro das políticas sociais no governo Lula
}

\author{
The Future of Social Policy in the Lula Government
}

As políticas sociais estão contribuindo para o crescimento econômico e redução das desigualdades sociais? Essa, inegavelmente, é uma questão central no debate sobre essa temática, sobretudo nesse início de século, quando a média de crescimento do Produto Interno Bruto (PIB) brasileiro tem oscilado entre $0,13 \%$ em 1998 e 2,28\% em 2005, superando esses índices apenas em 2000 e 2004. E as políticas sociais, em especial a de previdência social, vêm sendo sistematicamente acusadas de retrair os investimentos e impedir o crescimento econômico.

Não devemos esquecer que as políticas sociais, mais do que simplesmente garantir acesso a bens e serviços, são importantes mecanismos de realização de direitos de cidadania, e foram estratégias fundamentais de expansão do Estado social e do crescimento econômico no período conhecido como os 'anos de ouro' do capitalismo, entre as décadas de 1940 e 1970, sob os auspícios da regulação econômico-social de matiz keynesiana-fordista. Mesmo o avanço avassalador do neoliberalismo nas décadas de 1970 e 1980 não foi capaz de desmantelar as políticas sociais nos países europeus, e a média de gastos com políticas sociais permanece em torno de $22 \%$ do PIB. Elas continuam sendo elementos fundamentais na estratégia de ampliação do consumo de bens básicos, aumento da demanda agregada e geração de emprego no setor público e privado.

No Brasil, a perspectiva de implantação de um amplo padrão de políticas sociais, previsto na Constituição de 1988, vem sendo fortemente tencionada pelas estratégias de extração de superlucros e supercapitalização, com a privatização explícita ou induzida de setores de utilidade pública, onde se incluem saúde, educação e previdência. A incorporação das clássicas medidas neoliberais estabelecidas nos acordos firmados pelo governo brasileiro com o Fundo Monetário Internacional (FMI) desde 1998 - juros altos, redução do aparato estatal, políticas focalizadas, privatização - constitui uma combinação explosiva, que mina a possibilidade de expansão das políticas sociais e sua capacidade de redistribuir renda e reduzir desigualdades sociais.

Os direitos previstos constitucionalmente não foram nem uniformizados e nem universalizados. Diversas contra-reformas, como a da previdência de 1998, 2002 e 2003, sendo as primeiras no governo Fernando Henrique Cardoso e outra no governo Lula, restringiram direitos, reforçaram a lógica do seguro, reduziram valor de benefícios, abriram caminho para a privatização e para a expansão dos planos privados, para os fundos de pensão, ampliaram o tempo de trabalho e contribuição para obter a aposentadoria. No âmbito da política de saúde, a fragilização da atenção básica está levando a saúde se caracterizar como 'cesta básica'. Os princípios do sistema único de saúde, como descentralização, participação democrática, universalização e integralidade das ações estão sendo diluídos pela manutenção cotidiana de uma 'cesta básica' que não assegura nem mesmo os atendimentos de urgência. É notória e fartamente noticiada a falta de medicamentos e as longas filas de espera. No âmbito da política de assistência social não se conseguiu, até o momento, superar a compreensão equivocada da focalização em segmentos e situações bem específicas. A abrangência desta política é ainda muito restrita: hoje os benefícios, serviços e programas não atingem mais do que $25 \%$ da população que teria direito, com exceção do Benefício de Prestação Continuada e do Bolsa Família, que vêm crescendo nos últimos anos. O Sistema Único de Assistência Social (SUAS) se propõe a ampliar e remodelar esta política, mas até o momento sua extensão e estruturação ainda estão longe de abranger todos os municípios brasileiros.

Os sucessivos ajustes físcais realizados nos últimos anos fazem com que o comportamento da alocação 
de recursos para as políticas sociais, e de modo específico para a seguridade social, assuma um caráter regressivo e restritivo, o que permite apenas o desenvolvimento de mecanismos compensatórios, que focalizam as políticas sociais nas camadas mais pobres da população, e que não alteram profundamente a estrutura das desigualdades sociais. A forte ampliação da carga tributária brasileira não tem se revertido em ampliação de políticas sociais universais e redistributivas. Ao contrário, nossa carga tributária é regressiva, porque os impostos e contribuições incidem sobre os trabalhadores e o consumo. Assim, a tributação não promove redistribuição de renda e riqueza; ao contrário, contribui para sua concentração.

Apesar do aumento de arrecadação do orçamento da seguridade social, que passou de $6,12 \%$ do PIB em 1999 para $12,39 \%$ em 2005, as reformas da previdência foram efetivadas mediante a alegação de um suposto déficit, sendo que o próprio Tribunal de Contas da União (TCU), ao analisar as contas do Governo Federal de 2005, reconheceu que não há déficit na previdência. O que ocorre é uma realocação dos recursos do orçamento da seguridade social para pagamento dos juros da dívida pública e geração do superávit primário: a Desvinculação das Receitas da União (DRU) permitiu ao Governo Federal retirar R \$ 45,2 bilhões do orçamento da seguridade social entre 2002 e 2004, que deveriam ser utilizados para as políticas de previdência, saúde e assistência social e poderiam ampliar os direitos relativos a estas políticas sociais. Essa tendência, já expressa por muitos analistas, também está indicada em artigos desta revista.

Com parcos investimentos diante da dimensão da pobreza e das desigualdades sociais, cai a possibilidade de expansão e universalização das políticas sociais e estas assumem caráter focalizado e seletivo, destinadas apenas à população em situação de pobreza absoluta, sob rigorosos critérios de acesso, como é o caso do Programa Bolsa Família. É inegável que esse programa, assim como o Benefício de Prestação Continuada (BPC) assegurado na Lei Orgânica de Assistência Social (LOAS) e a aposentadoria dos trabalhadores rurais, tem um importante efeito na ampliação dos rendimentos dos beneficiários e conseqüente ampliação de seu acesso ao consumo de bens básicos. Mas é também inquestionável que seu caráter ex-post, seus baixos valores e seus rígidos e muitas vezes vexatórios critérios de acesso conseguem apenas minorar os efeitos mais perversos da pobreza extrema, sem causar impactos estruturais na redução das desigualdades sociais e na desconcentração da riqueza.

As perspectivas para as políticas sociais no segundo mandato do presidente Lula serão determinadas pela orientação da política macroeconômica: elas podem se constituir em elementos e estratégias importantes para alavancar o crescimento econômico e re- duzir as desigualdades sociais, ou podem ser compreendidas como entraves ao crescimento econômico.

Se a segunda possibilidade prevalecer, a tendência será de restrição de direitos, nova reforma da previdência social sem incorporação dos trabalhadores que hoje estão no mercado informal, permanência da DRU, estagnação ou crescimento vegetativo do orçamento da seguridade social, manutenção do Bolsa Família como estratégia de transferência de rendimento sem articulação com políticas de inserção em empregos estáveis, pífio crescimento econômico e queda na qualidade da saúde pública. O conteúdo das políticas sociais não será determinado, como muitos reiteram, por uma presumível onipotência do mercado, mas sim resultado de uma opção política e econômica do atual governo.

\section{Ivanete Boschetti}

Doutora em Sociologia pela Ecole de Hautes Etudes en Sciences Sociales

Professora do Departamento de Serviço Social

Universidade de Brasília - UnB 